\title{
PEMAHAMAN AYAT MISOGINI DALAM AL-QUR'AN: (Analisis terhadap Metode Penafsiran Muhammad Mutawalli al-Sya'rawi)
}

\author{
Zubaidi \\ Institut Agama Islam Negeri Kudus \\ Email : zubaidipati@gmail.com
}

\begin{abstract}
Misogini in the Qur'an is an understanding of the verses of the Qur'an in Surah AnNisa which contain various problems related to the relationship between men and women both as humans and as husband and wife in a household life or in social, cultural, and political life. Among the many issues concerning women, the inferiority (women as subordinates, inferior and not good), while men are superioritas (human superior, leader). The purpose of this study is to describe the views on household leadership, beatings of women, women's testimony and inheritance, by scholars and in particular by AlSya' rawi. The research method used is library research (library research) by examining the views or thoughts of Al-Sya'rawi on the misogyny verse in the Qur'an. The results in the study show that Al-Sya'rawi sees, understands the verses of the Qur'an that seem to be detrimental to women, actually not harming women, but as justice of Allah SWT. and for the benefit of the woman herself.
\end{abstract}

Keywords: Misogini, Inferioritas, Superioritas

\begin{abstract}
Abstrak
Misogini dalam Al-Qur'an adalah pemahaman terhadap ayat Al-Qur'an dalam Surat An-Nisa yang memuat berbagai persoalan yang berkaitan dengan relasi antara laki-laki dan perempuan baik sebagai manusia maupun sebagai suamiistri dalam suatu kehidupan rumah tangga atau dalam kehidupan sosial, budaya, dan politik. Di antara sekian banyak isu tentang wanita adalah inferioritas (wanita sebagai manusia bawahan, rendah dan kurang baik), sedangkan pria merupakan superioritas (manusia atasan, pemimpin). Tujuan dari penelitian ini adalah mendeskripsikan pandangan tentang kepemimpinan rumah tangga, pemukulan terhadap wanita, kesaksian wanita dan warisan, oleh para ulama dan khususnya oleh Al-sya'rawi. Metode penelitian yang digunakan studi kepustakaan (library research) dengan menelaah pandangan atau pemikiran Al-Sya'rawi terhadap ayat misogini dalam Al-Qur'an. Hasil penelitian ini menunjukkan bahwa al-Sya'rawi melihat, memahami ayat-ayat Al-Qur'an yang kelihatannya merugikan wanita, sebenarnya bukan merugikan wanita, tapi sebagai keadilan Allah SWT dan untuk kemaslahatan wanita itu sendiri.
\end{abstract}

Kata Kunci: Misogini, Inferioritas, Superioritas 


\section{PENDAHULUAN}

Misogini dalam Al-Qur'an adalah pemahaman terhadap ayat AlQur'an yang merendahkan kedudukan wanita, sedangkan memahami kedudukan wanita dalam Islam merujuk kepada Al-Qur'an, terutama surat An-Nisa', di dalamnya merupakan salah satu surat Al-Qur'an yang paling banyak memuat persoalan yang berkaitan dengan hak-hak dan kewajiban perempuan. Menurut Sayyid Rasyid Ridha, surat ini dinamakan An-Nisa' karena pada awal pembukaannya menuturkan tentang perempuan dan hukum-hukum yang berkenaan dengan mereka (Syafiq, 2001: 44).

Surat An-Nisa' memuat berbagai persoalan yang berkaitan dengan relasi antara laki-laki dan perempuan baik sebagai manusia maupun sebagai suami-istri dalam suatu kehidupan rumah tangga atau dalam kehidupan sosial, budaya, dan politik. Meskipun demikian, tidak semua isi surat tersebut berisi tentang persoalan-persoalan yang berkaitan dengan kehidupan perempuan laki-laki saja, surat ini juga membuat persoalan-persoalan lain. Namun, dari beberapa surat yang terdapat di dalam Al-Qur'an, An-Nisa' ini memang surat paling banyak menyoroti seluk beluk yang berkaitan dengan perempuan. Demikian pendapat yang dikemukakan pengarang Tafsir Al-Manar (Syafiq, 2001: 45).

Di antara sekian banyak isu tentang wanita adalah inferioritas wanita sebagai manusia bawahan, rendah dan kurang baik, sedangkan pria merupakan superioritas (manusia atasan, pemimpin). Wanita diciptakan tidak sama dengan pria, karena itu, wanita berada dalam lingkup yang sesuai yaitu ruang domestik. Isu semacam ini telah memasyarakat karena dianggap mempunyai dasar kaidah-kaidah ilmiyah atau ajaran yang diatas namakan Islam dengan dalil Al-Qur'an maupun hadist Rasul. Hal ini merupakan akibat dari pemahaman dan penafsiran atau interprestasi masa dulu yang sulit diterima pada masa sekarang. Kesalahpahaman tersebut merupakan akar dari berbagai masalah yang timbul tentang wanita. Khususnya dalam kehidupan berkeluarga. Disamping kehidupan publik atas isu-isu tersebut dinyatakan dan disepakati sebagai kodrat wanita, menjadi pandangan interior terhadap wanita. Misalnya tentang asal penciptaan wanita, kemampuan akal dan agama serta ruang lingkupnya (Zaitunah, 1999: 41-42).

Ada beberapa artikel penelitian yang memiliki relasi terhadap penelitian penelitian yang dikaji, berjudul "Kedudukan Suami-Istri (Kajian Surah An-Nisa' [4]: 34)", dalam artikel tersebut mengkaji tentang kedudukan suami dan istri dalam Islam, serta menjelaskan bahwa kedudukan laki-laki lebih tinggi dari perempuan, hal ini dimaksudkan untuk mempertegas pembagian tugas antara laki-laki sebagai suami dan perempuan selaku isteri (Rahmawati, 2018). 
Adapun dalam artikel lain "Hadis Misoginis Perspektif Gender Dan Feminisme", penelitian tersebut menganalisis bagaimana kemunculan hadits-hadits yang menunjukkan ketidakadilan pada perempuan melalui pendekatan feminisme dan gender dengan sejarah yang mendampinginya. Hasilnya menunjukkan bahwa terdapat tiga formulasi pembacaan kaum feminis terhadap hadits misogini. (Ade, 2019). Pada tahun yang sama, terbit sebuah artikel yang mengkaji secara spesifik tentang keberadaan perempuan dalam ayat-ayat al-Qur'an dan Bibel yang terdapat dalam Qur'an: a Reformist Translation. (Siti, 2019). Kebaharuan dalam kajian ayat-ayat misogini dalam al-Qur'an mendapat perhatian khusus yakni bagaimana ayat-ayat misoginis yang berisi bias gender al-Qur'an dan tafsir menjadi salah satu khas epistemologi kajian tafsir kontemporer (Sherly, 2020).

Diantara beberapa penelitian terdahulu belum ada yang membahas secara spesifik ayat-ayat misoginis dalam al-Qur'an menurut pandangan al-Sya'rawi. Kajian ini menjadi penting untuk dilakukan karena akan memberikan khazanah keilmuan Islam. Penelitian ini bertujuan mengkaji pandangan Al-sya'rawi tentang kepemimpinan pria, pemukulan terhadap wanita, kesaksian wanita dan warisan.

\section{METODE PENELITIAN}

Penelitian ini menggunakan metode kepustakaan (library research) menggunakan berbagai sumber kepustakaan sebagai sumber data penelitian. Penelitian ini adalah telaah yang berkaitan kepada pemikiran seorang tokoh dalam waktu tertentu, maka secara metodologis pendekatan yang digunakan adalah pendekatan isi perpustakaan. (Nyoman, 2010:39) Maksudnya adalah penelitian berhubungan erat dengan pemikiran yang dituangkan dalam karya atau buku (isi), yaitu penelitian berbicara tentang pandangan tokoh mengenai keadaan yang semestinya dalam membangun suatu keadaan yang semestinya berdasarkan konsep yang telah disistematiskan kemudian dihubungkan dengan keadaan atau kondisi suatu benda, tempat, dan keadaan. maka pendekatan yang digunakan selain kualitatif juga dengan pendekatan ekspresif (berhubungan dengan pengarang), pendekatan objektif (berhubungan dengan teks), pendekatan mimetik (berhubungan dengan kesemestaan) dan pendekatan pragmatik yang berhubungan dengan resepsi pembaca terhadap teks (Suwandi, 2003: 9). 


\section{PEMBAHASAN}

\section{Kepemimpinan Pria}

Suatu kepemimpinan sangat dibutuhkan dalam kehidupan rumah tangga. Rumah tangga pada umumnya memberi pengertian sebuah keluarga yang terdiri dari suami, istri dan anak-anak pada umumnya. Keluarga merupakan suatu institusi yang menyimpan isu dan proplematika yang berkepanjangan. Problematika yang muncul dari kehidupan berumah tangga atau keluarga senantiasa aktual apalagi dalam situasi dan pola masyarakat yang selalu berubah. Kondisi yang seperti ini membutuhkan seorang pemimpin yang mampu dan punya kelebihan untuk menyelesaikan persoalan, demi kelestarian tujuan kehidupan berkeluarga (harmonis, damai, tenang, dan tentram) sebagaimana tercantum dalam surat Al-Rum 30 ayat 21 (Zaitunah, 1999:101).

Isu yang banyak didiskusikan dalam diskursus feminism belakangan ini adalah konsep kepemimpinan rumah tangga. Para feminis muslim menggugat faham kepemimpinan suami dalam rumah tangga yang selama ini sudah mapan di kalangan kaum muslimin. Bagi mereka faham yang menempatkan suami sebagai pemimpin rumah tangga tidak sejalan, bahkan bertentangan dengan ide utama feminisme yaitu kesetaraan laki-laki dan perempuan. Sebagai konsekuensi dari konsep kesetaeaan laki-laki dan perempuan itu maka dalam sebuah rumah tangga, kata meraka, status istri setara dengan status suami. (Yunahar, 1997: 73).

Konsep kepemimpinan suami atas istri, sebagaimana yang diyakini oleh umat Islam umumnya itu, berasal dari pemahaman terhadap firman Allah SWT dalam surat Al-Nisa' ayat 34, maka para Feminim Muslim setidak-tidaknya Asghar Ali Engineer dan Aina Wadud Mushin. Berupaya untuk melakukan penafsiran kembali terhadap ayat tersebut, tentu saja setelah membongkar penafsiran lama yang mereka nilai sebagai bias gender. (Yunahar, 1997:73). Allah SWT berfirman dalam Al-Qur'an surat al-Nisa' ayat 34:

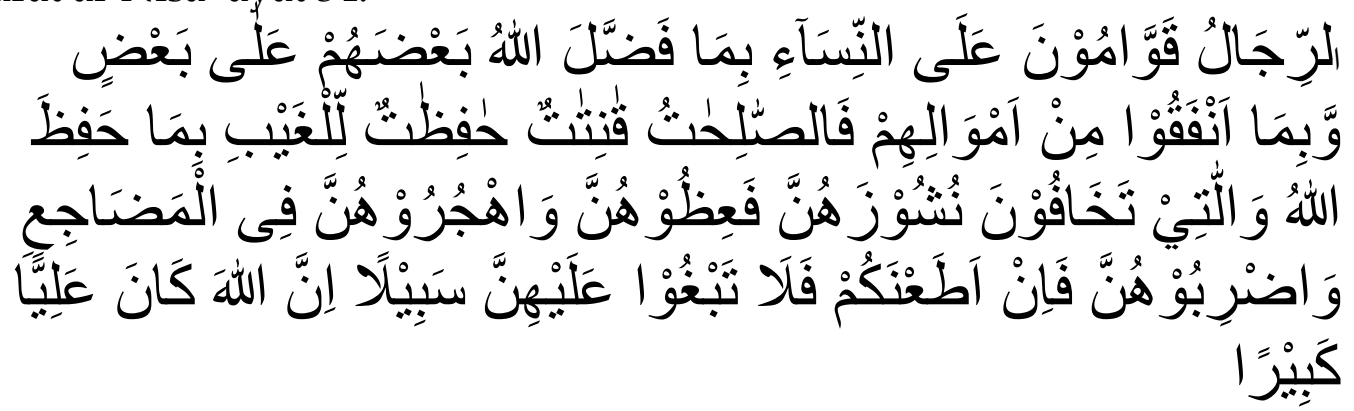

Artinya : "Laki-laki (suami) itu pelindung bagi perempuan (istri), karena Allah telah melebihkan sebagian mereka (laki-laki) atas sebagian yang lain (perempuan), dan karena mereka (laki-laki) telah memberikan nafkah 
dari hartanya. Maka perempuan-perempuan yang saleh adalah mereka yang taat (kepada Allah) dan menjaga diri ketika (suaminya) tidak ada, karena Allah telah menjaga (mereka). Perempuan-perempuan yang kamu khawatirkan akan nusyuz, hendaklah kamu beri nasihat kepada mereka, tinggalkanlah mereka di tempat tidur (pisah ranjang), dan (kalau perlu) pukullah mereka. Tetapi jika mereka menaatimu, maka janganlah kamu mencari-cari alasan untuk menyusahkannya. Sungguh, Allah Maha Tinggi, Maha Besar".

Berdasarkan ayat tersebut, Zamakhisyari, Alusi dan Sa'id Hawwa sepakat menyatakan bahwa suami adalah pemimpin terhadap istrinya dalam rumah tangga. Kalimat kunci yang menjadi landasan pendapat mereka adalah ar-rijalu qawwamuna ala al-nisa'. Oleh Zamakhisyari kalimat tersebut ditafsirkan dengan yakummuna alaihinna amirna nahina kama yaqumu al-wulatu ala al-ri'aya, summu qawwaman lidzalik yang artinya kaum laki-laki berfungsi sebagai yang memerintah dan melarang kaum perempuan sebagaimana pemimpin berfungsi terhadap rakyatnya, dengan fungsi itu laki-laki dinamai qawwam). Dengan reaksi yang berbeda Alusi menyatakan hal yang sama dengan Zamakhsyari : "al aya'nuhum al-aiyamu alaihinna aiyama al-wulati ala al-ra'yati ni al-amri wa al nahyi wa nahwi dzalik... (maksudnya tugas kaum laki-laki adalah pemimpin kaum perempuan sebagaimana pemimpin-memimpin rakyatnya yaitu dengan perintah, larangan dan yang semacamnya). Sedangkan Sa'id Hawwa menafsirkan dengan redaksi yang persis sama dengan Zamakhsyari (Yunahar, 1997: 75).

Ketiga mufasir tersebut sepakat menafsirkan kata qawwah dengan pemimpin. Atas dasar makna qawwah itulah mereka sepakat menyatakan bahwa dalam rumah tangga, suamilah yang menjadi pemimpin bagi istrinya. Mari kita lihat selanjutnya bagaimana mereka manafsirkan alas an kepemimpinan laki-laki yang terdapat dalam ayat tersebut: bi ma faddhalallahu ba'dhahum'ala ba'dh, wa bi ma anfaqu, in amwalihim" (oleh karena Allah telah melebihkan sebagian mereka (laki-laki) atas sebagian yang lain (perempuan), dank arena mereka (laki-laki) telah menafsirkan sebagian dari harta mereka (Yunahar, 1997: 76).

Ayat al-rijalu qawwamuna ala al nisa' biasanya dijadikan sebagai salah satu rujukan, karena ayat tersebut berbicara tentang pembagian kerja antara suami-istri. Memahami pesan ayat ini, ada dua butir prinsip yang melandasi hak dan kewajiban suami-istri, yaitu :

1) Terdapat perbedaan antara pria dan wanita, bukan hanya pada bentuk fisik mereka. Tetapi juga dalam bidang psikis,. Bahkan menurut Dr. Alexis Carreel salah seorang dokter yang pernah meraih dua kali hadiah nobel- pebedaan tersebut berkaitan juga dengan kelenjar dan darah masing-masing kelamin. Pembagian kerja, hak dan kewajiban 
yang ditetapkan agama terhadap kedua jenis manusia itu didasarkan oleh perbedaan-perbedaan itu.

2) Pola pembagian kerja yang ditetapkan agama tidak menjadikan salah satu pihak bebas dari tuntutan minimal dari segi moral untuk membantu pasangannya.

Ibnu Hazm seorang ahli hukum Islam berpendapat wanita pada dasarnya tidak berkewajiban melayani suami dalam hal menyediakan makanan, menjahit, dan sebagainya. Justru sang suamilah yang berkewajiban menyiapkan pakaian jadi, dan makanan yang siap di makan untuk istri dan anak-anaknya (Quraishshihab, 1996: 310-311).

Sementara itu, menurut Zamakhsyari ada dua alasan kenapa lakilaki yang memimpin perempuan dalam rumah tangga, pertama, karena kelebihan laki-laki atas perempuan, kata ganti hum pada kalimat "bima" faddhalallahu ba'dhuhum ala $b a^{\prime} d h$, menurut Zamakhsyari, berlaku untuk kedua-duanya, laku-laki dan perempuan. Dengan demikian ayat tersebut berarti "oleh karena kelebihan yang diberikan Allah kepada sebagian mereka yaitu laki-laki atas sebagian yang lain yaitu perempuan". Menurut dia mengutip pendapat-pendapat yang beredar sebelumnya tanpa menyebut sumbernya, kelebihan-kelebihan laki-laki itu adalah kelebihan akal, keteguhan hati, keimanan keras, kekuatan fisik, kemampuan menilis pada umumnya, naik kuda, memanah, menjadi Nabi, Ulama', kepala Negara, imam shalat, jihad, azan kutbah, I'tikaf, bertakbir pada hari tasyrik, menurut Abu Hanifah, kesaksian dalam hudud, dam qishash. Tambahan bagian dan mendapatkan sisa dalam pembagian, al-hamalah, al qusamah, menjadi wali pernikahan, menjatuhkan talak, menyatakan rujuk, boleh berpoligami, nama-nama anak di nisbatkan kepada mereka, serta punya jenggot dan surban. Kedua adalah laki-laki membayar mahar dan pengeluaran nafkah keluarga (Yunahar, 1997: 76).

Menurut Sayyid Qutub kepemimpinan laki-laki terhadap wanita bukan berarti meremehkan dan merendahkan wanita dalam rumah tangga, masyarakat dan hukum, akan tetapi kepemimpinan laki-laki terhadap wanita dalam rumah tangga adalah untuk menjaga wanita, memberi kasih saying dan tanggung jawab terhadap diri, anak dan hartanya (Sayyid, tt: 652).

Pada dasarnya tidak ada perbedaan antara para mufasir dan feminis muslim bahwa yang dimaksud dengan pernyataan Al-Qur'an al rijalu qawwamuna 'ala al-nisa' dalam surat An-Nisa' ayat 34 adalah laki-laki sebagai pemimpin atas istri dalam rumah tangga. Perbedaan terjadi dalam menilai apakah pernyataan Al-Qur'an itu bersifat normatif atau kontekstual. Apabila bersifat normatif, maka kepemimpinan laki-laki dalam rumah tangga bersifat permanen, sudah merupakan norma yang tidak dapat diubah lagi, sebaliknya kalau bersifat kontekstual 
kepemimpinan rumah tangga disesuaikan dengan konteks sosial tertentu. Apabila konteks sosialnya berubah dengan sendirinya doktrin ini akan berubah, artinya belum tentu laki-laki menjadi pemimpin.

Menurut Quraish Shihab kepemimpinan laki-laki adalah tentang pembagian kerja dalam rumah tangga, beliau menjelaskan agama tidak menjadikan salah satu pihak bebas dari tuntutan, minimal dari segi moral membantu pasangannya. Adapun Al-Sya'rawi lebih memahami lafadz qawwamuna adalah tanggung jawab baik nafkah ataupun urusan keluarga, pendapat al- Sya'rawi hamper sama dengan pendapat Asghar Ali Engineer, yang mengartikan qawwam sebagai pemberi nafkah atau mengatur urusan keluarga.

Dalam pembahasan penelitian lebih lanjut, pendapat Al-Sya'rawi itu tidak lepas dari konteks sosial budaya masyarakat di mana beliau hidup. Karena di Mesir waktu beliau hidup ada sebagian laki-laki yang bersikap otoriter terhadap istrinya, begitu juga adanya sebagian laki-laki yang menganggur, tidak bekerja, sehingga ank istrinya terlantar, maka alSya'rawi mempunyai pemahaman tentang lafal qawwamun suami wajib bekerja, berusaha, bergerak dalam segala bidang kehidupan untuk kebutuhan istri dan keluarganya. Penafsiran-penafsiran yang telah dikemukakan tadi sangat dipengaruhi social budaya para penafsir hidup.

Menurut pendapat penulis laki-laki memang menjadi pemimpin bagi wanita, tetapi kepemimpinannya bukan dengan semena-mena dan menang sendiri. Kepemimpinan lebih bersifat tanggung jawab, melindungi, mencukupi kebutunnya, memberi rasa aman, damai dalam keluarganya. Dengan adanya laki-laki sebagai pemimpin wanita akan diarahkan dengan baik dan bijaksana, sedang laki-laki bersikap tanggung jawab ia akan selalu bertanggung jawab terhadap istri dan keluarganya, sehingga akan terjadi keseimbangan dan ketentraman dalam rumah tangga.

\section{Pemukulan Terhadap Wanita}

Istri sesungguhnya mempunyai kewajiban untuk patuh kepada suami sebagai pemimpin rumah tangga, sebagaimana telah disebutkan diatas, maka apabila istri nusyuz (tidak menjalankan kewajiban sebagai istri, tidak patuh atau melawan kepada suaminya), suami berhak bertindak dalam tiga tahapan : 1) menasehatinya/fa'izhuhunna; 2) pisah ranjang /wahjuruhunna fi al-madhaji'i; dan 3) memukulnya/wa adhribuhunna (Ali Shabuni, tt: 274).

Menurut Sayyid Qutub pemukulan terhadap wanita dalam kasus istri nusyuz setelah diperingatkan, dipisah dari tempat tidur, baru dipukul dengan syarat pemukulan yang bukan berupa penyiksaan, membahayakan, meremehkan dan menghina. Akan tetapi pemukulan 
ringan tersebut bertujuan mendidik dengan kasih saying seperti yang dilakukan seorang ayah terhadap anaknya. (Sayyid, tt: 654).

Para mufassir sepakat dengan pemahaman seperti ini dalam menghadapi istri yang nusyuz seperti terdapat dalam ayat yang dibahas. Cuma saja untuk langkah yang ketiga, ketiga mufassir sepakat memberi catatan bahwa pukulan yang dibenarkan adalah pukulan yang tidak menyakitkan (ghair mubarraj) yaitu pukulan yang tidak melukai, tidak mematahkan tulang dan tidak merusak muka (Yunahar, 1997: 81). Mengenai pemukulan terhadap istri yang nusyuz memang suami diberi hak untuk melakukan tiga tahapan tindakan menghadapi istri yang nusyuz, yaitu menasehati, pisah ranjang, memukul. Ini merupakan pendapat kebanyakan para mufasir yang memberikan syarat memukunya tidak membahayakan istri.

Hanya saja Al-Sya'rawi ketika menjelaskan lafadz fa adhribuhunna tidak berarti Allah memerintah untuk memukul wanita (istri), tetapi diperbolehkan dengan syarat tidak menyakitkan. Al-Sya'rawi sudah memberi maksa yang sangat moderat yaitu ketika memahami lafat $f a$ adhribuhunna, bukan perintah tetapi diperbolehkan, akan tetapi menurut penulis kalau masih diperbolehkan hal ini masih disalah fahami oleh sebagian orang yang masih tetap mukul istrinya gara-gara hal yang sepele karena ada dasarnya ia melakukan hal tersebut. Firman Allah dalam surat Al-Nisa' ayat 34 bahwa lafadz wa adhribu hunna bukan berarti Allah memerintahkan untuk memukul wanita, tetapi itu bias diperbolehkan dengan syarat tidak menyakitkan (tidak membahayakan), itupun dengan syarat setelah diperingatkan dan kalau tidak berhasil maka berpisah dari tempat tidur. Baru yang ketiga (terakhir) boleh dipukul dengan syarat tidak menyakitkan (dalam arti untuk mendidik).

Al-Sya'wari juga berpendapat bahwa antara "diperintahkan" dengan "dibolehkan" mengandung perbedaan yang sangat jauh dalam memahami makna "wa adhribu hunna" karena pemahaman ulama' ulasik, bahwa lafadz "wa adhribu hunna" adalah perintah Allah untuk memukul, maka banyak laki-laki yang memukul istrinya sampai mengalami luka yang berat bahkan kematian dan hal ini jelas tidak dibenarkan oleh Islam. "wa adhribu hunna" dalam pandangan Al-Sya'rawi adalah boleh, namun bila tidak dengan memukul maka hal itu lebih baik, karena Rasul Saw. sendiri tidak pernah memukul wanita. Al-Sya'wari mengatakan, memukul yang tidak menyakitkan adalah menunjukkan cintanya suami pada istri, yang menurut pemahaman penulis seperti mencubit, bukan berarti mencubit berbuat aniaya pada istri tapi ada rasa cinta dan sayang pada istri (Al-Sya'rawi, tt: 80).

Selanjutnya, Dalam ayat fa adhribuhunna mestinya harus ditafsirkan dengan ayat lain seperti "wa'asyiruhunna bi al-ma'ruf" yaitu agar suami memperlakukan dengan baik dan bijaksana walaupun istri dalam 
keadaan nusyuz. Sehingga tidak sampai terjadi pemukulan terhadap wanita, bahkan Nabi Saw. pernah bersabda bahwa tangannya tidak pernah dipakai memukul wanita. Jika terjadi kekerasan tersebut seperti kekerasan psikis maupun fisik, akan memberikan dampak buruk bagi perempuan seperti mengalami sakit fisik, tekanan mental, menurunnya rasa percaya diri dan harga diri, mengalami rasa tidak berdaya, mengalami ketergantungan pada suami yang sudah menyiksa dirinya, mengalami stress pasca trauma, mengalami depresi, dan keinginan untuk bunuh diri (Emi, 2012: 3).

\section{Kesaksian Wanita}

Pada prinsipnya kesaksian yang berpijak pada ayat-ayat Al-Qur'an dan biasa dijadikan dasar (kemudian dipahami) yaitu dengan menentukan dua orang saksi pria atau (kalau tidak ada makna) satu orang pria serta dua orang wanita. Sehingga dapat dipahami bahwa nilai satu orang pria sama sama dengan dua orang wanita. Dengan kata lain dapat dipahami bahwa nilai satu orang wanita adalah separuh (seperdua) dari nilai pria dalam kesaksian maupun warisan (Zaitunah, 1999:115).

Sebagaimana dijelaskan tentang hukum akhir riba mulai dari ayat 275 sampai dengan ayat 281, maka pada ayat 282, Al-Qur'an memberikan tuntutan bagaimana dilakukan transaksi kredit dilakukan secara tertulis dengan disaksikan oleh dua orang laki-laki dan dua orang perempuan. Transaksi tertulis itu diperlukan untuk mengantisispasi terjadinya perselisihan atau pengingkaran di kemudian hari (Yunahar, 1997:90). Sebagaimana dalam firman Allah Swt. dalam Surat Al-Baqarah ayat 282:

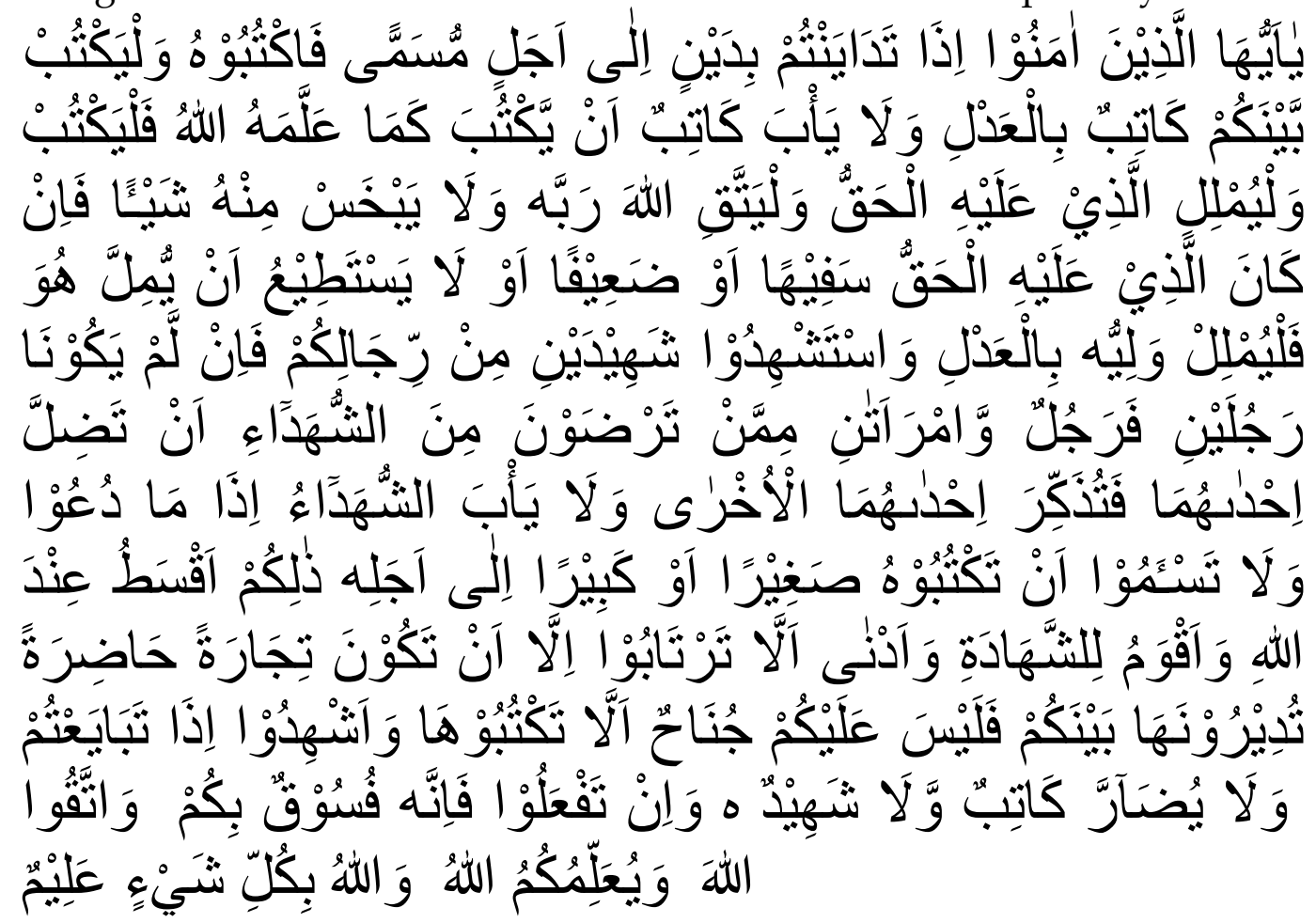


Artinya : "Wahai orang-orang yang beriman! Apabila kamu melakukan utang piutang untuk waktu yang ditentukan, hendaklah kamu menuliskannya. Dan hendaklah seorang penulis di antara kamu menuliskannya dengan benar. Janganlah penulis menolak untuk menuliskannya sebagaimana Allah telah mengajarkan kepadanya, maka hendaklah dia menuliskan. Dan hendaklah orang yang berutang itu mendiktekan, dan hendaklah dia bertakwa kepada Allah, Tuhannya, dan janganlah dia mengurangi sedikit pun daripadanya. Jika yang berutang itu orang yang kurang akalnya atau lemah (keadaannya), atau tidak mampu mendiktekan sendiri, maka hendaklah walinya mendiktekannya dengan benar. Dan persaksikanlah dengan dua orang saksi laki-laki di antara kamu. Jika tidak ada (saksi) dua orang laki-laki, maka (boleh) seorang laki-laki dan dua orang perempuan di antara orang-orang yang kamu sukai dari para saksi (yang ada), agar jika yang seorang lupa, maka yang seorang lagi mengingatkannya. Dan janganlah saksi-saksi itu menolak apabila dipanggil. Dan janganlah kamu bosan menuliskannya, untuk batas waktunya baik (utang itu) kecil maupun besar. Yang demikian itu, lebih adil di sisi Allah, lebih dapat menguatkan kesaksian, dan lebih mendekatkan kamu kepada ketidakraguan, kecuali jika hal itu merupakan perdagangan tunai yang kamu jalankan di antara kamu, maka tidak ada dosa bagi kamu jika kamu tidak menuliskannya. Dan ambillah saksi apabila kamu berjual beli, dan janganlah penulis dipersulit dan begitu juga saksi. Jika kamu lakukan (yang demikian), maka sungguh, hal itu suatu kefasikan pada kamu. Dan bertakwalah kepada Allah, Allah memberikan pengajaran kepadamu, dan Allah Maha Mengetahui segala sesuatu".

Berdasarkan ayat di atas Allah SWT memberikan ketentuan bagi orang yang melakukan transaksi atau perjanjian keterikatan yang tidak tunai dengan cara kredit, yang menggunakan prasarana suatu bukti sebagai dasar untuk mengantisipasi perselisihan yang mungkin timbul (yang tidak diinginkan) dikemudian hari. Pembuktian ini berupa bukti tercatat dan saksi. Perjanjian (mu'amalah misalnya jual beli yang tidak kontan) dicatat atau ditulis oleh seorang atas kesepakatan kedua belah pihak (bila menyuruh orang ketiga sebagai juru tulis). Saksi ialah orang yang melihat atau menyaksikan terjadinya suatu peristiwa. Saksi merupakan dalalah atau alat bukti yang dapat dijadikan dasar dalam menyelesaikan suatu masalah (Zaitunah, 1999: 116).

Menurut Zamakhsyari seperti telah disebutkan dalam ayat 282 surat Al-Baqarah diperlukan dua kesaksian perempuan sebagai ganti kesaksian seorang laki-laki supaya jika yang satu lupa, yang lain mengingatkannya. Zamakhsyari tidak menjelaskan lebih lanjut kenapa 
perempuan diprediksi untuk lupa, sementara laki-laki tidak (Yunahar, 1997:92). Sedangkan Menurut Alusi diperlukan dua orang saksi perempuan sebagai ganti satu orang saksi laki-laki karena perempuan memang mempunyai sifat pelupa (Yunahar, 1997: 58) Sa'id Hawwa, mengutip pendapat Sayyid Quthub, mengemukakan dua sebab. Pertama, karena perempuan tidak banyak berpengalaman dalam urusan transaksi sehingga mudah lupa detail-detailnya, kedua, karena sifat perempuan yang cenderung emosional (infi'aliyah). Satu sifat yang memang diperlukan oleh seorang ibu untuk merespon tuntutan bayinya tanpa harus berfikir secara mendalam (Sayyid, tt: 662).

Selanjutnya, mengenai kenapa kalau tidak ada dua saksi laki-laki harus dipakai formula satu laki-laki dua perempuan. Untuk menggantikannya dapat disimpulkan ada 3 penyebabnya : pertama sebab yang bersifat kadrati, yaitu perempuan pelupa dan emosional (Alusi \& Said Hawwa), kedua kurang pengalaman dalam transaksi dan bisnis (Asghar), ketiga kemungkinan adanya kekuatan luar yang akan memaksanya untuk memberikan kesaksian palsu (Amina).

Menurut Al-Sya'rawi syahadah yaitu sesuatu yang dilihat secara nyata atau fakta, walaupun Al-Sya'rawi tidak sependapat dengan ulama' yang mengatakan wanita pelupa atu emosional, atau kurang pengalaman dalam urusan keuangan, dari sini dapat dilihat pemikiran Al-Sya'rawi yang menghormati dan memuliakan wanita, hanya saja Al-Sya'rawi memberi alasan kenapa persaksian dua wanita sama dengansatu laki-laki menurutnya wanita adalah mahluk tetutup. Dalam arti menjauhi segala sesuatu yang dianggap membahayakan dirinya, kedua tabiat wanita tidak ingin ikut campur dalam pertengkaran, pertikaian, ketiga, wanita jika mendapatkan kejadian yang membahayakan ia tertekan hatinya. Alasan Al-Sya'rawi tersebut tidak mutlak karena di setiap masyarakat tentu ada perbedaan sosial budaya, hanya saja karena beliau hidup di Mesir yang budaya wanitanya yang beliau jelaskan.

Menurut Sayyid Qutub dalam memberi kesaksian dua wanita sama dengan satu laki-laki tujuannya untuk mengingatkan antara yang satu dengan yang lain. Menurutnya watak sebagian wanita itu sediit kecerdasannya tentang akad atau transaksi, sehingga ia tidak mampu menguasai dengan baik. Watak wanita juga terpengaruh dengan perasaannya, karena tabiatnya sebagai ibu bagi anak (Sayyid, tt: 336). Dalam hal kesaksian wanita Al-Sya'rawi berpendapat bahwa makna lafadz syahadah dalam ayat 282 surat Al-Baqarah berasal dari kata masyhad, yaitu sesuatu yang anda lihat, secara kenyataan atau fakta. Kata syahadah di sini tidak membutuhkan ilmu dan penelitian ilmiah tapi yang diperlukan adalah penglihatan yang benar, menyaksikan suatu perkara yang terjadi (Al-Sya'rawi, tt: 75). 
Dalam hal kesaksian wanita Al-Sya'rawi berpendapat bahwa makna lafadz syahadah dalam ayat 282 surat Al-Baqarah berasal dari kata masyhad, yaitu sesuatu yang anda lihat, secara kenyataan atau fakta. Kata syahadah di sini tidak membutuhkan ilmu dan penelitian ilmiah tapi yang diperlukan adalah penglihatan yang benar, menyaksikan suatu perkara yang terjadi (Al-Sya'rawi, tt: 75).

Kesaksian wanita harus dua orang. Itu lebih bertujuan untuk kehati-hatian yang dalam disebut "an tudhilla ihdahuma fatudzakkira ukhra". Yaitu untuk saling mengingatkan antara satu dengan yang lain. Alasan yang dijelaskan para mufasir dan Al-Sya'rawi itu dapat dipadukan dan saling melengkapi sesuai soaial dan budaya suatu masyarakat. Artinya jika masyarakat yang bebas, wanitanya lebih terbiasa melihat atau melakukan pertengkaran dan pertikaian seperti di Negara barat. Sedangkan wanita di Negara muslim atau timur, wanitanya tidak terbiasa melihat atau melakukan pertengkaran atau pertikaian, sehingga alasan Al-Sya'rawi dan para mufasir dapat berbeda.

\section{Warisan Wanita}

Salah satu kesalahfahaman yang sering terjadi mengenai status wanita dalam Islam ialah perbedaan jenis kelamin dalam urusan warisan. Argumen yang digunakan secara konsisten ialah bahwa seorang lelaki mendapat warisan dua kali lipat dari wanita. Beberapa krikitus dengan mudah menyimpulkan dari sini bahwa amat berbeda dengan pria dalam Islam. Sebagaimana dijelaskan dalam surat An-Nisa' ayat 11:

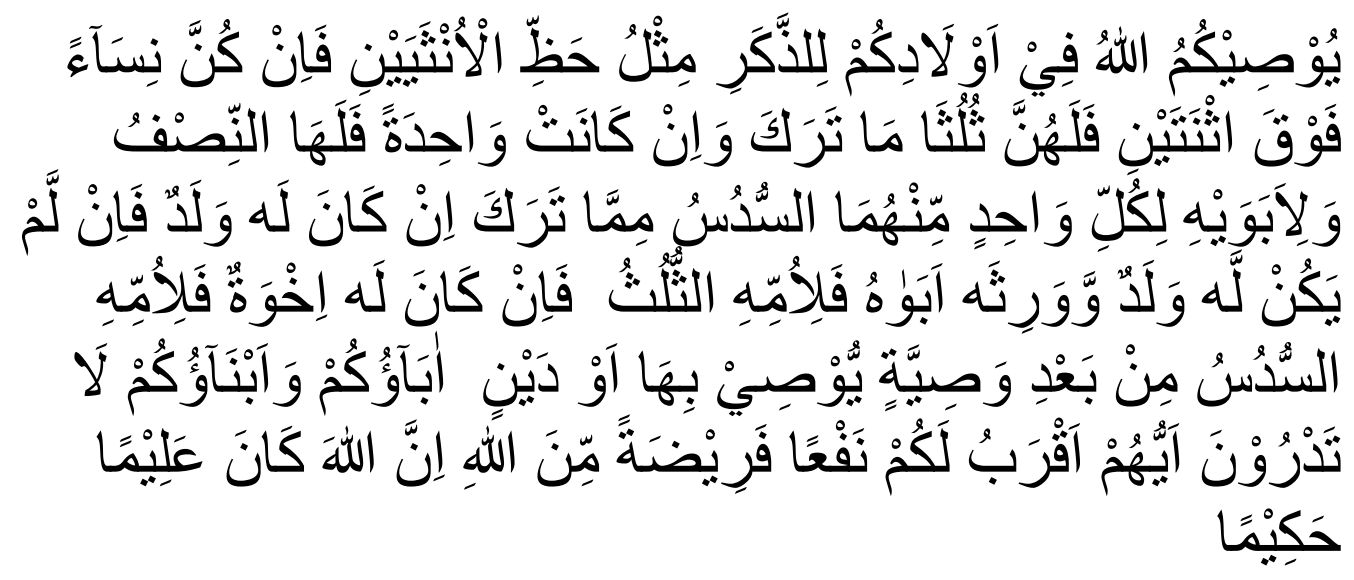

Artinya : "Allah mensyariatkan (mewajibkan) kepadamu tentang (pembagian warisan untuk) anak-anakmu, (yaitu) bagian seorang anak laki-laki sama dengan bagian dua orang anak perempuan. Dan jika anak itu semuanya perempuan yang jumlahnya lebih dari dua, maka bagian mereka dua pertiga dari harta yang ditinggalkan. Jika dia (anak perempuan) itu seorang saja, maka dia memperoleh setengah (harta yang ditinggalkan). Dan untuk kedua ibu-bapak, bagian masingmasing seperenam dari harta yang ditinggalkan, jika dia (yang 
meninggal) mempunyai anak. Jika dia (yang meninggal) tidak mempunyai anak dan dia diwarisi oleh kedua ibu-bapaknya (saja), maka ibunya mendapat sepertiga. Jika dia (yang meninggal) mempunyai beberapa saudara, maka ibunya mendapat seperenam. (Pembagian-pembagian tersebut di atas) setelah (dipenuhi) wasiat yang dibuatnya atau (dan setelah dibayar) utangnya. (Tentang) orang tuamu dan anak-anakmu, kamu tidak mengetahui siapa di antara mereka yang lebih banyak manfaatnya bagimu. Ini adalah ketetapan Allah. Sungguh, Allah Maha Mengetahui, Mahabijaksana".

Menurut Zamakhsyari, dalam surat An-Nisa' ayat 11 tidak bermaksud menyebutkan kekurangan anak perempuan, karena AlQur'an tidak mengungkapkannya dengan kalimat li al-untsayaim mitslu hazhzh al-azakar (dua anak perempuan mendapat bagian separuh bagian anak laki-laki). Dua kalimat pengandaian mengesankan kekurangan perempuan.

Lebih lanjut, Zamakhasyari menyebutkan bagian anak laki-laki dan dengan demikian mendapat dua kali bagian anak perempuan. Akan tetapi Zamakhasyari tidak menguraikan lebih lanjut kepada anak laki-laki sebagai jenis kelamin, atau karena tanggung jawab nafkah yang harus dipikulnya? Zamakhasyari menyebutkan bahwa karena bangsa Arab sebelum ayat ini turun tidak memberi hak waris kepada kaum perempuan, sebagaimana yang sudah dijelaskan dalam latar belakang turunnya ayat diatas, maka sudah cukup bagi laki-laki mendapat bagian dua kali perempuan tanpa harus mengharamkan sama sekali perempuan mendapatkan warisan. (Yanuar, 1997:102). Dari uraian tentang warisan wanita Zamakhsyari, Said Hawwa, Asgar, sepakat menyatakan bahwa formula warisan 2:1 tidaklah bersifat diskriminatif terhadap perempuan, formula seperti itu berdasarkan atas keadilan berimbang antara hak dan kewajiban.

Menurut Sayyid Qutub, bagian laki-laki dua kali lipat dari bagian perempuan merupakan keseimbangan dan keadilan dalam syariat Islam. Laki-laki menanggung semua kebutuhan keluarga, anak dan istrinya. Sedangkan wanita hanya menanggung dirinya sendiri, ia tidak wajib menanggung keluarganya. (Sayyid, tt:592). Sedangkan Alusi berpendapat bahwa anak-anak perempuan mendapat bagian kurang dibandingkan bagian anak laki-laki, karena kekurangan akal dan agama mereka sebagaimana dijelaskan oleh hadist, karena kebutuhan mereka terhadap harta lebih sedikit di banding kebutuhan anak laki-laki, karena suamisuami mereka telah menjamin biaya hidup mereka, dan karena nafsu mereka lebih besar sehingga bisa jadi harta menyebabkan mereka lebih jujur (Yanuar, 1997: 103). 
Oleh karena itu, hukum waris tidak dapat diambil untuk menyimpulkan perbandingan status wanita dan pria dalam Islam. Mengingat bahwa ada situasi-situasi dimana wanita mempunyai bagian yang lebih besar ataupun lebih kecil dari pada pria. Sesungguhnya bagian yang lebih tinggi biasanya diberikan kepada mereka yang kebutuhannya lebih besar, supaya mereka dapat melaksanakan kewajiban finansial mereka. Pertimbangkanlah, sisalnya, seorang saudara lelaki dan seorang saudara perempuan dalam keluarga, termasuk di saudara perempuan. Apabila ia kawin, ia membayar mahar dan bertanggung jawab secara finansial atas istri dan anak-anak. Bilamana saudara perempuannya kawin, dia menerima mas kawin dan diurusi oleh suaminya secara finansial. Apabila ia tidak kawin maka saudara lelakinya bertanggung jawab atasnya (Abdurrahim, 1997: 65).

Menurut Al-Sya'rawi wanita hidupnya semua ditanggung oleh pria, dialah yang bertanggung jawab nafkah wanita baik sebagai bapak, suami, kakak. Maka adil kalau laki-laki lebih banyak. Al-Sya'rawi melihatnya secara tekstual (normatif) beliau belum melihat fakta/kenyataan suatu masyarakat yang wanita bekerja, mencari nafkah, bahkan menanggung keluarganya yang laki-laki sehingga beliau memberi alasan pria yang memegang semua nafkah wanita atau beliau memberi alasan jika pria titanggung hidupnya oleh wanita, pria tersebut akan menjadi hina.

Pemikiran dan alasan Al-Sya'rawi tidak benar secara mutlak, karena ada masyarakat yang wanitanya lebih pandai dan giat mencari nafkah, bahkan menghidupi keluarganya. Al-Qur'an lebih adil karena bagian pada laki-laki du kali lipat dari perempuan karena tanggung jawabnya yang berat, tetapi hal ini tidak mutlak, karena pada waktu tertentu wanita lebih banyak mendapat bagian dari pad laki-laki seperti dalam ayat 11-12 surat An-nisa'.

\section{SIMPULAN}

Berdasarkan pembahasan di atas, maka dapat disimpulkan bahwa Al-Sya'rawi tergolong ulama yang tradisionalis, konservatif tapi beliau mempunyai ide dan pendapat yang moderat dan baru, yang dapat diterima oleh masyarakat dengan cara menggabungkan pendapat ulama salaf dan ulama modern, yaitu tanpa meninggalkan nash-nash yang ada dan tidak mengesampingkan pendapat-pendapat baru sesuai dengan situasi dan kondisi masyarakat modern.

Pemahaman Al-Sya'rawi yang moderat dan baru dapat dilihat dari pemahaman beliau terhadap kata qawwamuna ala al-nisa', yang menurut beliau adalah lafadz "qawwam" bukan bernama pemimpin tapi adalah tanggung jawab. Yaitu bertanggung jawab memenuhi kebutuhan istri, anak-anaknya dan urusan rumah tangganya. Tentang pemukulan 
terhadap wanita Al-Sya'rawi mengatakan bahwa ayat tersebut Allah Swt. tidak memerintahkan memukul istri, tapi, memperbolehkannya, itu saja kalau sudah dengan cara diperingatkan, dipisahkan dari tempat tidur, baru boleh dipukul, Al-Sya'rawi juga menjelaskan pemukulan tersebut tidak membahayakan, seperti mencubit, sedikit memukul yang hal tersebut menunjukan cintanya suami terhadap istri. Mengenai AlSya'rawi tidak menyatakan bahwa 2 saksi wanita sebanding 1 saksi pria. Bukan karena kurang pandainya wanita (akalnya) atau pelupa tapi beliau lebih menekankan bahwa tabiat wanita tidak suka menyaksikan pertengkaran, dengan detail sehingga dalam persaksian harus 2 orang wanita. Dalam masalah warisan menurutnya karena wanita hidupnya selalu ditanggung oleh laki-laki ia tidak banyak beban sehingga ia mendapatkan $1 / 2$ nya laki-laki, tapi dalam keadaan tertentu wanita pun bisa mendapat bagian lebih.

\section{DAFTAR PUSTAKA}

\section{Buku-Buku}

Abdurrahim Umran "Islam dan KB" terjemahan Muhammad Hasyim, Jakarta : Lentera Basri Tama, cet. I. 1997.

Emi Sutrisminah, “Dampak Kekerasan Pada Istri Dalam Rumah Tangga Terhadap Kesehatan Reproduksi", Majalah Ilmiah Sultan Agung, Vol. 50, No.127, 2012

Muhammad Mutawalli al-Sya'rawi, Al Marwah fi al-Qur'an al-karim, Kairo : Akhbar Al Yaum, t.t.

Nyoman Kutha Ratna, Teori, Metode, dan Teknik Penelitian Sastra, Dari Strukturalisme Hingga Postrukturalisme Wacana Naratif, Yogyakarta: Pustaka Pelajar, 2010.

Quraish Shihab, Wawasan Al Qur'an Tafsir Maudhu'I Atas Pelbagai Persoalan Umat, Bandung : Mizan, Cet. I. 1996.

Sayyid Qutub, “Tafsir Fi Dhilal al-Qur'an ",Kairo, Dar al-Syuruq t.t., jilid II.

Shabuni, Ali, al-Shafwah al-Tafasir, Beirut: Dar al-Fikr, t.th, vol. II

Suwardi Endraswara, Metodelogi Penelitian Sastra: Epistemologi, Model, Teori dan Aplikasi, Yogyakarta: Caps, 2003.

Syafiq Hasyim, Hal-hal yang Tak Terpikirkan tentang Isu-isu Perempuan dalam Islam, Bandung: Mizan, Cet. I, 2001.

Yahunar Ilyas, Feminisme dalam Kajian Tafsir Al-Qur'an Klasik dan Kontemporer, Yogyakarta : Pustaka Pelajar, Cet. I. 1997.

Zaitunah Subhan, Tafsir Kebencian Bias Gender dalam Tafsir Qur'an, Yogyakarta : LKis. Cet. I. 1999. 


\section{Jurnal-Jurnal}

Rahmawati Hunawa, "Kedudukan Suami-Istri (Kajian Surah An-Nisa' [4]: 34)", Journal Potret: Jurnal Penelitan dan Pemikiran Islam, Vol.22, No.1, 2018

Ade Marhamah, "Hadits Misoginis Perspektif Gender Dan Feminisme", AT-TIBYAN: Journal Of Qur'an and Hadis Studies, Vol. 2, No. 2, 2019.

Sherly Dwi Agustin, "Wacana Misoginis Dalam Diskursus Tafsir Akademis: Kajian Epistemologis atas Jurnal Tahun 2010-2019", Mushaf: Jurnal Tafsir Berwawasan Keindonesiaan, Vol.1, No.1, 2020.

Siti Asiah, "Penafsiran Ayat-Ayat Misoginis dalam Perspekif Quran: a Reformist Translation", Jurnal Al-Irfani STAI Darul Kamal NW Kembang Kerang, Vol.5, No.1, 2019. 